\title{
Robert Burns Woodward: Three Score Years and Then?
}

\author{
David Dolphin \\ Department of Chemistry \\ University of British Columbia \\ Vancouver, British Columbia \\ Canada V6T 1W5
}

Synthetic organic chemistry began 150 years ago when, in 1828, Wöhler' ${ }^{2}$ prepared urea from ammonium cyanate. "The unexpected result," reported Wöhler, "is also a remarkable fact inasmuch as it presents an example of the artificial production of an organic, and so-called animal, substance from an inorganic substance." Liebig, who at this time was working in similar areas, initially doubted Wöhler's work but was soon convinced, however, of its correctness, and the two young chemists became close and lifelong friends. Only a decade after Wöhler's original discovery, he and Liebig. writing jointly on uric acid, asserted that. "The philosophy of chemistry will draw the conclusion that the synthesis of all organic compounds, as long as they are not a part of an organism, must be seen as not merely probable but certain." No $_{0}$ one has more completely fulfilled this prophecy than R.B. Woodward, who in 1965 was awarded the Nobel Prize for art in organic synthesis. Some of his most notable achievements are the synthesis of vitamin $B_{12}$, the most complex non-polymeric naturally occurring substance, as well as a series of other synthetic triumphs which have cach in their turn established standards of elegance and creativity for which most other organic chemists can only hope to strive.

How does one tell the chemical community anything about Woodward which either they do not already know, or which they cannot readily learn by consulting any of the numerous collections of biographical data? 1 could list here the more than 30 honorary degrees which have been bestowed on him, and which are recorded in a closet in Cambridge as an array of multi-

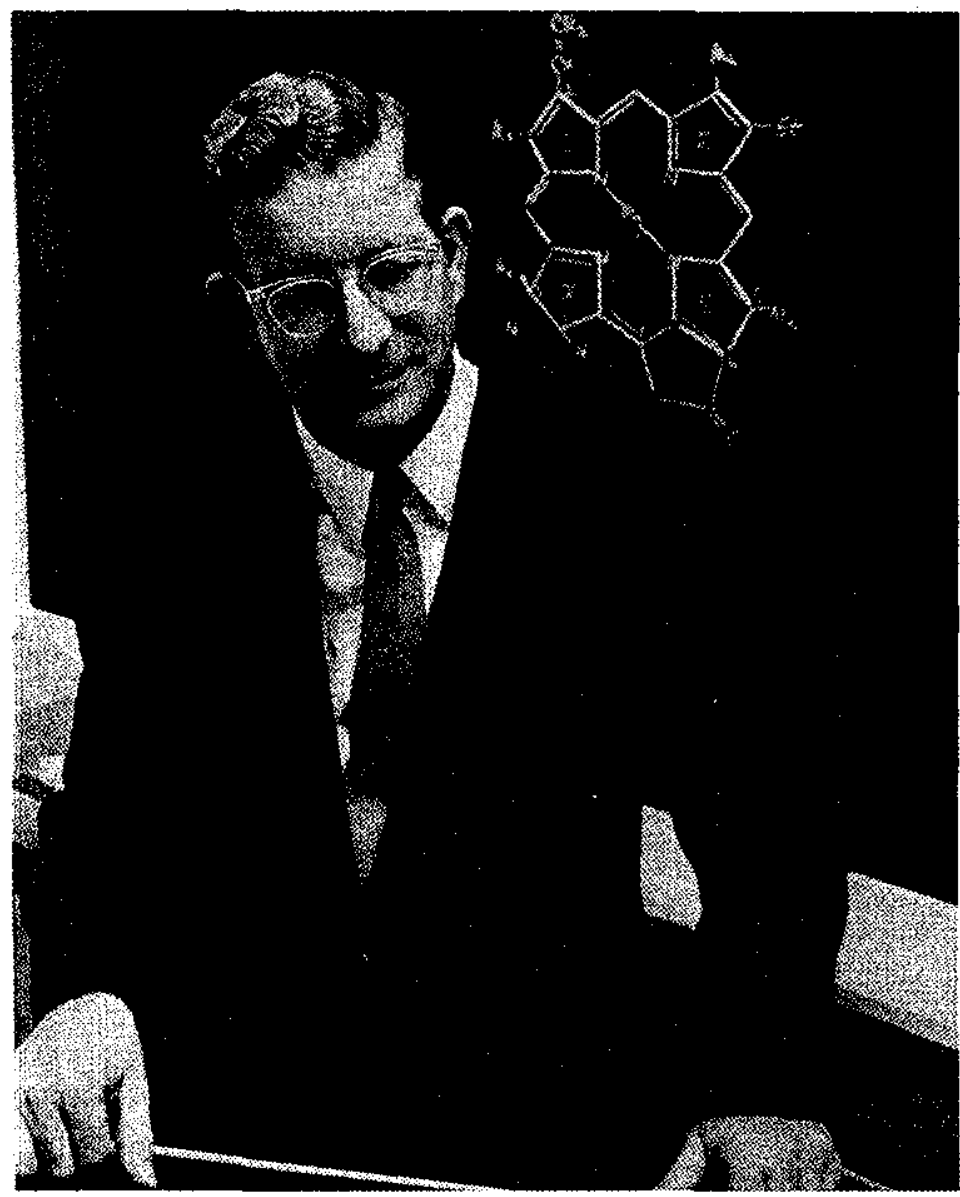

Fig. 1. Plan in detail, then carry it out (printed with permission of the American Chemical Society, from Chemical and Engineering News, Nov. 1965, p. 38).

This article was reproduced with permission from Aldrichimica Acta, Volume 10, Number 1, 1977. We greatly thank Dr. A. Bader and Dr. D. Dolphin for their kind help and co-operation. 
hued academic robes (with the exception of one from a Scottish University, which shall remain unnamed, which insisted that if Woodward wanted the gown, he would have to buy it!). And I could follow this by a list of awards which would include the Theodore William Richards Medal, the Roger Adams Award, the Willard Gibbs Medal, the Pjus XI Gold Medal, the $N$ ationat Medal of Science, the Nobel Prize in Chemistry, the Lavoisier Medal, the Decorated Order of the Rising Sun (Japan), and on into a list which would require more space for its completion than the Aldrichimica Acta has available. Rather than pursue this typical approach, I have decided to take a light-hearted look at the man as well as his chemistry. ${ }^{3}$

Neither teacher nor student of chemistry can have failed to have come across many of the contributions that R.B. Woodward has made to science in the past four decades. This was certainly true for me as an undergraduate. as well as a graduate of chemistry at the University of Nottingham where I worked with Alan Johnson in the early 60's. When it became clear that I would probably obtain my Ph.D., I asked my mentor what he would suggest I do after I was through at Nottingham, and he advised me that it might be good for my soul 10 go somewhere where 1 would be expected to work a little harder than I had been used to, and that I might think about trying to work with Woodward at Harvard. After some considerable agonizing 1 came to the conclusion that surely all of the rumors I had heard about this man, his work habits and those of his coltaborators, could not possibly be true, and that I should indeed see if Woodward would give me a postoloctoral appointment in his laboratories. Having prepared a carefully worded letter I took it along to Alan Johnson to see if it met with his approval, and I was told I would be wasting my time if 1 sent it since Woodward never replied to letters. I have since learned that this was a slight exaggeration: nonetheless, the letter was never sent. Instead, however, when a few days later I was present at a half-day symposium on Vitamin $B_{12}$ in London at the Royal Socicty, during one of the traditional tea breaks I was approached by an individual whom I knew, by the tell-tale cigarette and blue tie, could be none other than Woodward. Within ten seconds he ascertained that I did indeed wish to work with him. and suggested that I should write to his secretary and say that 1 would be arriving the following September.

Having made plans to cross the Atlantic in search of fame and fortune, I thought it advisable to familiarize myself in a general way with some of Woodward's work, and

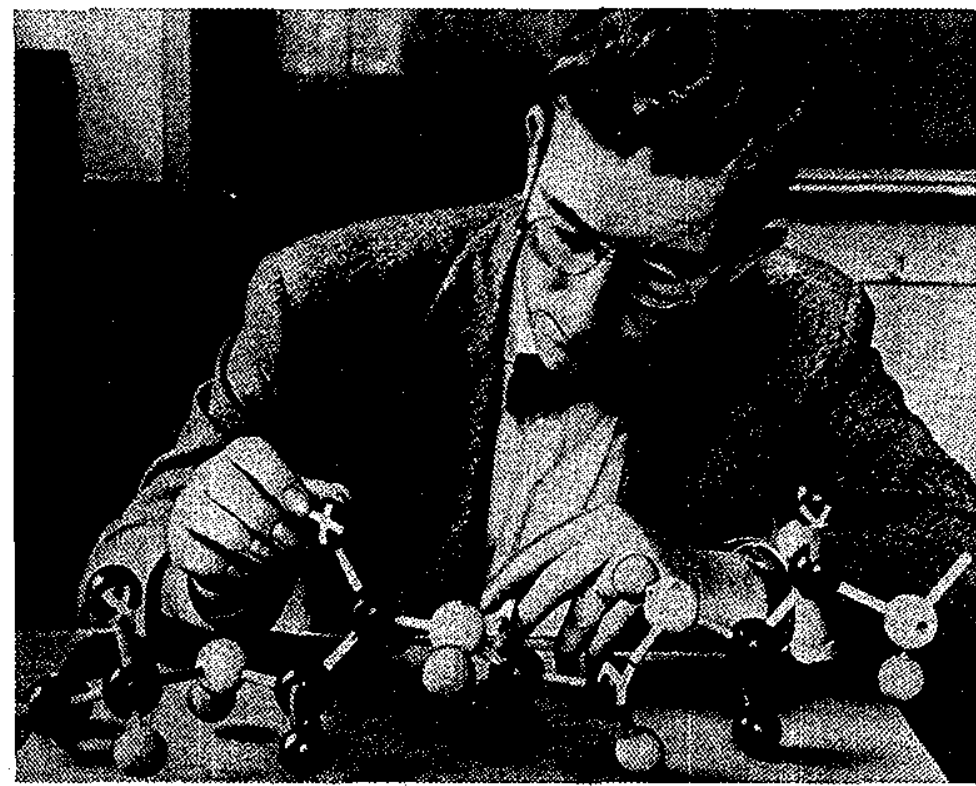

Fig. 2. RBW working with fibrous proteins (from the Boston Herald, Wednesday, June 18,1947 ).

am sure that you will be as interested as I was to note that his first two papers were:

Precipitation of barium in the coppertin group of qualitative analysis, W.J. Hall and R.B. Woodward, Ind. Eng. Chem., Anal. Ed., 6, 478 (1934).

The staling of coffee II, S.C. Prescott, R.L. Emerson, R.B. Woodward, and R. Heggie, Food Research, 2, 165 (1937).

But a glimpse of the greatness to come was evident in his third contribution to science:

A pressure regulator for vacuum distillation, R.L. Emerson and R.B. Woodward, Ind. Eng. Chem., Anal. Ed., 9, 347 (1937).

Arriving in Boston in the fall of 1965, I was met by his secretary, Dodie Dyer, and told if I would like to wait in the library Dr. Woodward would soon see me. And indeed, two weeks later, I was shown into his office, where we discussed what $l$ might do during my stay at $\mathrm{H}$ arvard and agreed that I would participate in the synthesis of $B_{12}$. Having established my scientific program for the period of my stay I turned my attention to more important matters such as the length of any holidays that I could expect. After a brief pause Woodward shrugged his shoulders and said, "Well, I take Christmas Day off."

During this first discussion I had been seated at the side of his desk. Convinced, as I am now, that Bob Woodward does nothing which he has not carefully thought out I have realized since that the small quotation 1 saw then in front of him was as much for the benefit of his colleagues as for him, and after slowly moving my position so that 1 was able to read it, at the conclusion of the interview I saw the words that were to encourage me in my work for the next year: "Let slecping dogs lie."

That year I spent in Woodward's laboratories was an especially exciting one and was highlighted early one morning when, as I walked into the laboratories, I heard the clinking of champagne glasses, and realized that although I had missed the news, the inevitable had obviously happened. The speed at which the champagne appeared in Bob's office surprised me, but I soon found out that, in fact, the cbampagne had been laid down by the department some time earlier in anticipation of the Nobel Prize. As the party progressed it was generally felt that signed champagne bottles would make a suitable memento of the occasion; however, it transpired that there were more drinkers than bottles. Woodward soon remedied this problem by holding sufficient parties until enough bottles had been accumulated. A few days later the Swedish television company came into Bob's laboratories and said how disap. pointed they were that they had missed the party, since they felt that scenes of a less formal nature might be suitable for a program they were preparing on that year's Nobel Laureate. Not wishing to disappoint his visitors from Sweden, Bob threw another round of parties which were receiv. ed by his group with no less enthusiasm 
than the initial ones.

Since he obtained the highest accolade in his field it might be of interest to see how Woodward's career had developed up to the time of the Nobel Prize. Born on April 10,1917 in Boston, Woodward spent his childhood in a suburb of that city, Quincy. To give you a brief glimpse of his child hood $I$ quote from an article in the Boston Daily Globe of June 8, 1937. "As a boy in short pants in Quincy Grammar School, he consistently brought home report cards dimmed with a pair of D's for conduct and effort. The Woodward youngster, who was always playing in the cellar with a chemistry set, received three double promotions hurdling the fourth, seventh and tenth grades, all the while whispering in classes, chewing bubble gum, being the last one in after recess and pulling little gir?s" long curls." I can assure you, after ten years of close association with Bob Woodward, that things have certainly changed since his earlier days - I don't think I have seen him blowing bubble gum in a long while.

In addition, it would appear that the passing years have also instilled a little caution. Recently, at an MIT fraternity house Pat ${ }^{4}$ introduced RBW to a striking young redhead who was interested in meeting him. Amid the din and accompanying revelry the two remained locked in an animated conversation. After some time RB, looking a little disillusioned, came over and said: "I find this young lady quite interesting. However, she has just made a strategic mistake." "What could she have done?" Pat queried, "Well," said RB, "she

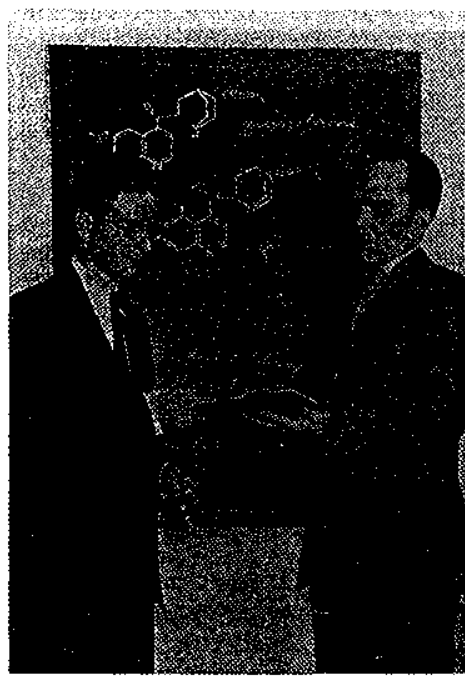

Fig. 3. Printed with permission of the American Chemical Society, from Chemical and Engineering News, 1944, p. 730. just told me that she had been engaged to a professional wrestler. And, Pat, that is a very hard act to follow."

Returning to the report from the Boston Globe we find that "in 1933, a sixteen yearold lad from Quincy with a very distinguished scholastic record appeared at MIT where professors, being only human, formed a quick but wrong impression of him. The savants at this institute solemnly soliloquized, "Woodward as a freshman had much to learn. He was in no position to think the world his oyster in or out of season, so happy-go-lucky, not at all the grim and studious type.'" One professsor had remarked, "Well, the Institute, young man, is a different place than a public school." It would appear then, as now, that MIT professors can be mistaken, for in four years Woodward had obtained his Ph.D. from MIT - not, however, without some difficulties. His transcript which shows a 4.9 out of a possible 5 was highlighted by a double $F$ in gym.

Clearly Woodward's career at MIT was atypical in that he obtained both his Bachelor's and Doctorate degrees by the age of 20 . Again quoting from the Boston Globe, "The achievement was the more remarkable in that Woodward obtained his goal after only four years of study against the seven usually required; when during this period much of his time had been devoted to outside work to finance his collegiate career."

"I never heard of it being done by any young man before, either at Tech or anywhere in the world," was the commendation of James Flack Norris, Professor of Organic Chemistry and Director of the Tech Research Laboratory in the field in which young Woodward took his degree.

While taking the regular freshman courses, during the first semester at the Institute, Woodward applied for a seat in the laboratory. The Organic Department told him that only graduate students, men who possess degrees, are allowed that privilege; but his appeal interested the Department and he was told that if he could supply a list of the experiments he was planning, he might be given some consideration. A few days later he produced a list of experiments that showed such outstanding originality and scope that he was granted a seat.

Toward the end of the second semester of his freshman year Woodward walked into the examination room where thirdyear students were being tested in organic chemistry. He inserted a note in his examination book, asking the professor to correct it, and if possible, to give him credit.
At the beginning of his second year he was given his own laboratory in which to experiment. In that year he happened to attend an organic chemistry lecture in which the professor told about the difficulty of synthesizing the female sex hormone from carbon. At the end of the lecture Woodward came to the professsor and showed him a way which might lead to such a synthesis.

The professor was amazed; the entire organic chemistry department became excited. For Woodward had hit on something that might prove to be revolutionary in the field of organic chemistry.

During his third year Woodward took as many as 15 courses in one semester so that he might receive his Ph.D. sooner. The faculty permitted him to spend as little time as he wished in classes. Instead he studied the required subject matter independently and simply presented himself at the examinations. Again and again he walked off with honors in organic chemistry courses. At the end of his third year Woodward was notified that he was to be granted a bachelor's degrec.

His last and fourth year at Tech, Woodward describes as his happiest, for he was able to spend his time in the research laboratory where he could resume his experiments, which he had begun in his second year at the Institute, on the female hormone. He did this work independently and wrote his thesis on it.

In explaining Tech's attitude toward Woodward, during that period of time. Professor Norris says, "We saw that we had in our midst a person who possessed a very unusual mind. We wanted to let it function at its best. If red tape, which was necessary for other less brilliant students, had to go, we cut it. We did for Woodward what we have done for no other student in our department, for we have had no student like him in our department. And we think he will make a name for himself in the scientific world." Norris further said, "But unlike some scholars, he will not burn out suddenly." It was not to be long before these prophesies were to be fulfilled.

Upon graduating from MIT Woodward spent the summer of 1937 at the Univetsity of Illinois but, with the approach of winter, migrated to warmer climes and moved back to Cambridge, where he became an assistant to Professor Elmer Peter Kohler at Harvard. The following year he was elected to the Harvard Society of Fellows, and by 1941 had published a serics of papers on ultraviolet spectral structure correlations which are still used to this day. In 1944 Woodward (as a consuitant for the Polaroid Corp.) and Bill Doering achieved 
the total synthesis of quinine in only 14 months (Fig. 3). In 1947 he was to elucidate the structure of strychnine, to be followed in 1954 by total synthesis of strychnine and lysergic acid. The synthesis of strychnine was not without its difficulties, however, and after several months of trying to close the 6 th ring, and after the most recent experiments had failed, Bob is recorded as saying. "If we can't make strychnine, we'l take strychnine!"

Prior to the total synthesis of strychnine both cholesterol and cortisone were synthesized, and in 1952 Woodward proposed the sandwich structure for ferrocene.

Few personal accounts of the major discoveries in chemistry are documented. An exception to this is the dream of August Kekules which led to the suggestion that benzene contained a cyclic structure. "There I sat and wrote my Lehrbuch," reported Kekulé, "but it did not proceed well, my mind was elsewhere. 1 turned my chair to the fireplace and fell half asleep. Again the atoms gamboled before my eyes. Smaller groups this time kept modestly to the background. My mind's eye, trained by repeated visions of a similar kind, now distinguished larger formations of various shapes. Long rows, in many ways more densely joined; everything in movement, winding and turning like snakes. And look. what was that? One snake grabbed its own tail, and mockingly the shape whirled before my eyes. As if struck by lightning I woke; this time I again spent the rest of the night to work out the consequences."

This dream of 1865 , occurred 35 years before Sigmund Freud's theories were published in $1900,{ }^{6}$ and one can but wonder about Freud's reaction to snakes' biting their own tails! If, however, this led to the elucidation of the structure of benzene, what thoughts led Woodward to the sandwich structure of ferrocene would, I am certain, prove fascinating.

While the suggested structure for ferrocene initiated an era of organometallic chemistry, it also aided in the demise of Woodward's continuing practice at the bench. A bout $3 \mathrm{a} . \mathrm{m}$. one day the group was gathered in the laboratory suggesting ways to try and oxidize or reduce the then-new. ferrocene. RB put a lump of $\mathrm{FeSO}_{4}$ into a separatory funnel and shook it with a solution of ferrocinium ion to reduce it. On being shaken, the funnel was broken by the lump, and the solution poured out onto RB's trousers (where it had the audacity to remain oxidized).

In 1960 Woodward announced the total synthesis of chlorophyll (Fig. 1), having already synthesized lanosterol and reserpine, and followed these successively with

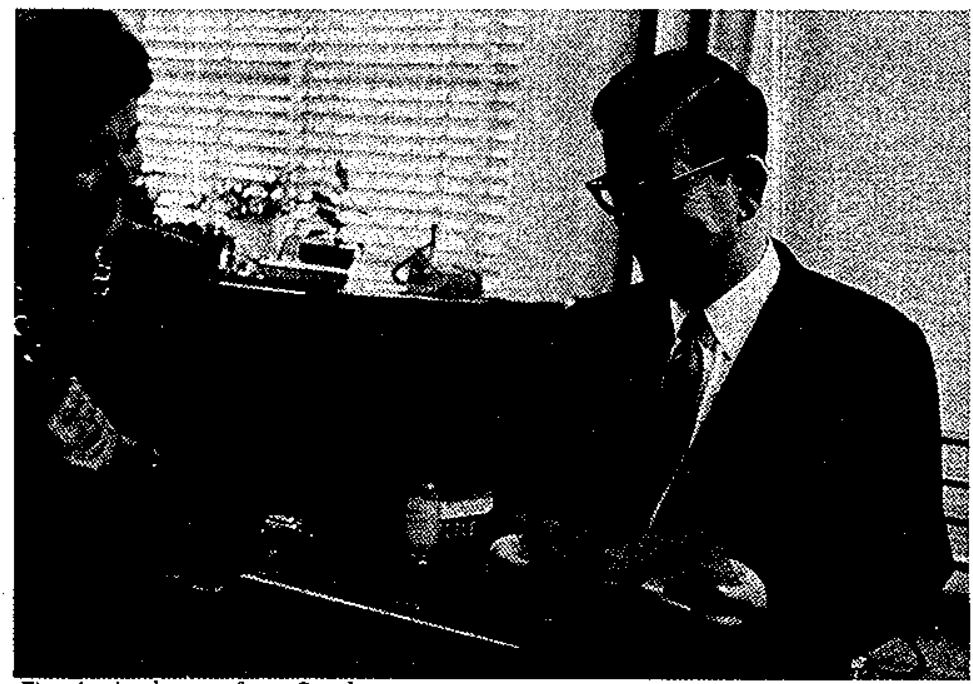

Fig. 4. A telegram from Sweden

syntheses of tetracycline, cortisone and cephalosporin during the period in which he was awarded the Nobel Prize (Fig. 4).

While I have chosen only a few of the highlights in the above list of achievements in synthesis, it must be remembered that the theoretical aspects of organic chemistry are areas to which Woodward has also turned his talents. The latest of these is the conservation of orbital symmetry developed by Woodward and Hoffmann in the late $60^{\circ}$ 's, and so elegantly summed up by them in their Angewandte Chemie article in 1968 where, in considering violations to the rules, they concluded "there are none!" Oosterhoff had suggested that orbital symmetry might play a role in electrocyclic reactions, and, while introducing Roald Hoffmann to an audience, made the observation that throughout the history of organic chemistry a number of significant contributions had been made by various distinguished Hoffmanns, among them being August Wilhelm von Hoffmann, and Friedrich Hoffmann. However, Oosterhoff noted, "of all the Hoffmanns the most famous is undoubtedly the Hoffmann whose first name is Woodward."

The greatest of all of Woodward's synthetic achievements is that of Vitamin $B_{12}$, which, in collaboration with Albert Eschenmoser, was completed in the early 70 's. As colloquia chairman at Harvard I persuaded Woodward to present a talk on the synthesis of $\mathrm{B}_{12}$. Our colloquia at $\mathrm{Har}$ vard were normally of an hour duration, and at first Bob was reluctant to lecture, since he assured me that there would be no way he could say his piece in an hour. If we were to schedule the talk at 5 p.m. as nor- mal, we might break into the dinner hour and upset the audience. We easily overcame these objections by starting the talk at 8 p.m. which of course left us the rest of the evening, and if necessary the following morning, for the remainder of the presentation. It had not gone unnoticed, on earlier occasions, that Woodward's talks had occupied several hours, and since I had no reason to expect that this occasion would be any different 1 felt it might be appropriate to give a more detailed than usual introduction of our speaker.

A few weeks earlier Duilio Arigoni had presented the Tishler lectureship to the department, and had been introduced by Woodward who took some delight in giving a detailed discussion of a horoscope that had been prepared for Arigoni. I remembered, too, that Woodward had told me several years earlier that one should use all available avenues to gain information about a subject. In particular I remember that Woodward was trying to repeat some of Thorpe's earlier work in which he had claimed to have synthesized some derivatives of tetrahedrane. By the time Woodward was attempting to repeat this work Thorpe had died and parts of the experimental details were no longer available. Woodward knew, however, that Lady Thorpe was a clairvoyant who claimed to be in touch quite regularly with her husband, so Bob thought that this might indeed be a unique way of obtaining information and would certainly constitute a novel footnote. It thus seemed appropriate to me that, in the absence of a clairvoyant, possibly a detailed analysis of a horoscope prepared for Woodward might be included in my own introduction. At the time of the 
preparation of Arigoni's horoscope, it had been suggested by the young lady preparing the horoscope, that perhaps Bob himself might like to have a horoscope prepared, but that in order to do this she would need the exact time, to the minute, of Woodward's birth. Woodward suggested that rather than use that time, which he didn't know anyway, and doubted that it could now be found, the young lady should prepare a horoscope for every minute of the day of his birth, and then by looking at the various comments decide what time he was born. Since 1 had neither the time nor the resources to undertake this obvious scientific but rather lengthy procedure, I determined to try and establish the exact time of Woodward's birth. A trip to the Massachusetts State House told me that Woodward was born on April 10, 1917 in the Boston Lying In Hospital for Women, but unfortunately no time had been recorded. However, the Boston Lying In Hospital for Women is an old established hospital and they informed me that for a small research fee they would check their records and find the information I needed, and behold a few days later a letter (Fig. 5) appeared recording Woodward's time of birth as 3:39 a.m. This is an especially significant time I feel, for I remember, one morning toward the end of a party in Bob's apartment, we saw the sun rise over the river Charles at about four in the morning. Woodward commented that yes, indeed he observed this every morning. Somewhat to our amazement he told us that he slept only three hours a day and had done so for as long as he could remember, and that he usually went to bed about $1 \mathrm{a} . \mathrm{m}$. and got up

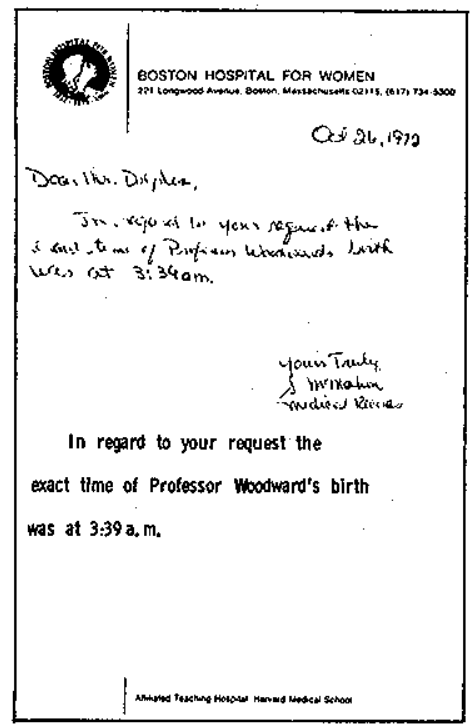

Fig. 5.

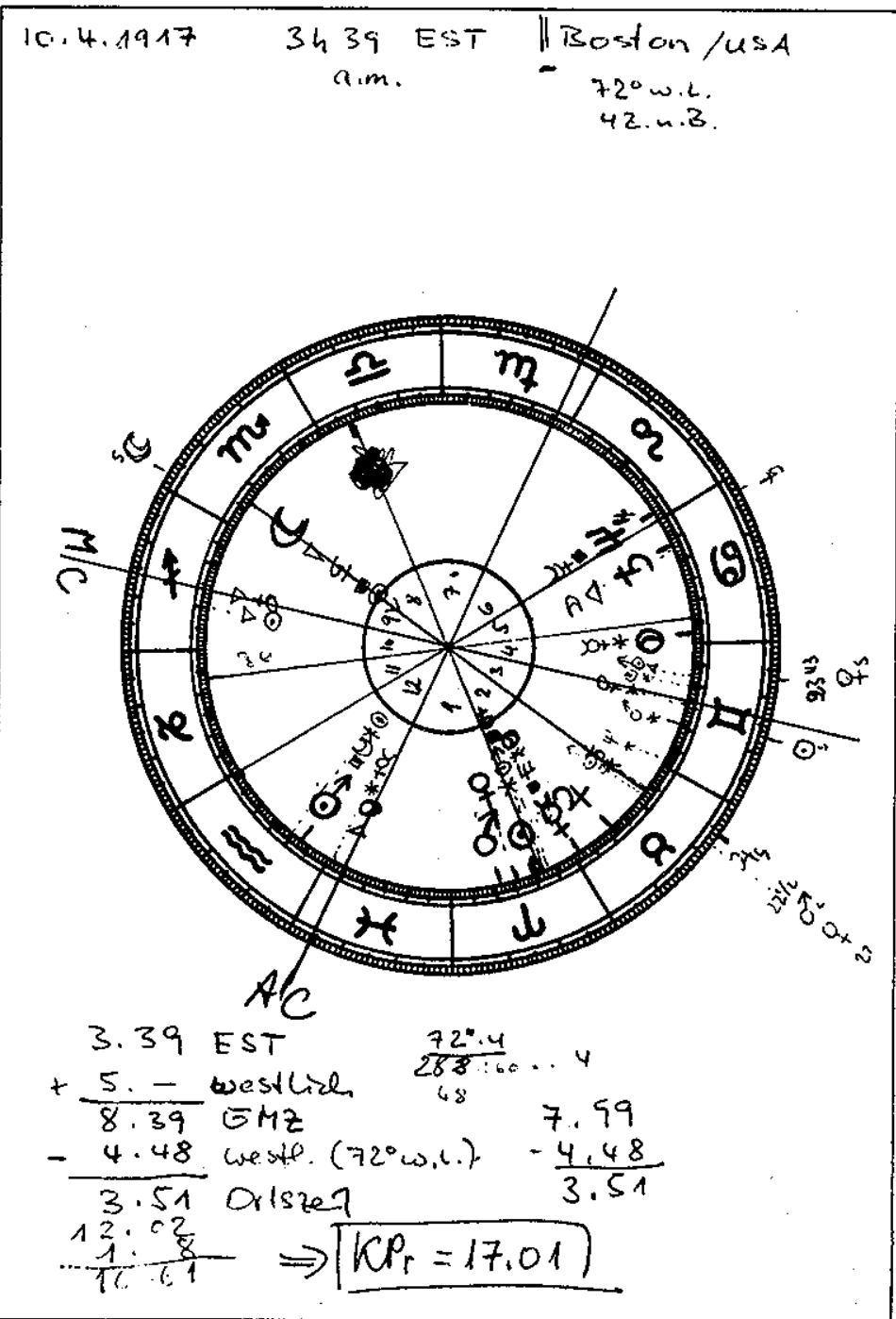

Fig. 6. Horoscope prepared for Woodward.

around 4 a.m. It would appear that he acquired this habit at a very young age then, and hasn't changed it since.

Having determined the exact time of Woodward's birth, I transmitted this information to Zürich and on the day of Woodward's lecture at Harvard, Arigoni flew in with the appropriate document and a somewhat detailed analysis of the horoscope. You will appreciate that it would be ignoble of me to outline here details of many of the comments that were made, but I reproduce in Fig. 6 the horoscope, so that those of you who are trained in the art of interpreting such documents can come to your own conclusions. I must make it clear right from the beginning that up until that time I had little faith in horoscopes, but many of the interpretations were indeed accurate in many respects; we knew we were on to a good thing with the first comment Woodward's favorite color was red! It was noted, however, that his career had begun at 22 , an accurate deduction, and that the man for whom this horoscope had been prepared should be a scientist. And not only that, that he should be a chemist, too. I must admit that to this day 1 do not know how much of this information came from the horoscope and how much came via Arigoni. The analysis went on to point out the subject was a user of nicotine and liquor, but was such a strong individual that 
these had no effect on his health. Woodward ran true to form to show us. that night, how accurate the statement was by consuming his usual number of packages of Benson \& Hedges and by finishing the two pints of Daiquiri that had been prepared for him as part of my introduction. Despite what non-smokers believe, among them such crusaders as James the First, who had this to say -

Smoking is a custom loathsome to the eye. hateful to the nose. harmful to the brain, dangerous to the lungs, and in the black stinking fumes there of nearest resembling the Stygian smoke of the pit that is bottomless.

- the habit has been a tradition amongst synthetic chemists since the time of Wobler and Liebig. both of whom were heavy smokers, especially Wöhter, who once made this comforting comment to a nonsmoking collcague: "there are examples of non-smokers who became bearable chemists; however, this occurs only rarely."

The horoscope indicated that the individual was forceful, energetic, had a good practical sense but was by no means diplomatic, and that he impressed others with his own personal viewpoint. And the individual was possessed with a phenomenal memory. To this 1 can personally attest. In late 1973 just before 1 left Harvard to move to the University of British Columbia, I was discussing the oxidizing power of oxaziridines with Woodward, who said that he recalled a paper from the Redstone Arsenal which he had read a while ago, where oxaziridines were titrated with iodide and hence oxidants. As a measure of Woodward's memory it transpires that the paper he referred to had been written about twenty years earlier, and that the iodide titrations were described in a footnote to the experimental section.

But let me return to Woodward's latest accomplishment. Although the total synthesis of $\mathbf{B}_{12}$, in the form of cobyrinic acid. formally represented a total synthesis of the vitamin itself, it was only a year ago that the complete synthesis was achieved, when the nucleotide loop was attached to the cobyrinic acid. (Fig. 7)

My latest count of the people involved in this undertaking, in both Cambridge and Zürich, totalled about 100 postdoctoral fellows. It is, of course, apparent that during the past 40 years Woodward's achievements must also be gauged in reference to Woodward as a teacher. During these past four decades nearly 400 students have been associated with him. It is said that a man can be judged by the company he keeps. and it is certainly true that a chemist can be measured by the men he has trained. It would be inappropriate to list here all 400 colleagues; other ventures being planned to celebrate Woodward's 60th birthday wil better measure the magnitude of this group. 1 have however gone through the list of Woodward's collaborators and randomly selected about ten percent of the names:

Bill Ayer. Jerry Berson, Ray Bonnett, Rich Borch. Axsel Bothner-By, Ron Breslow; Bill Chan, Malcolm Clark, Gerhard Closs, Pat Confalone, Pierre Deslongchamps. Bill Doering. Paul Dowd, Ian Fleming, Chris Foote. David Ginsburg. Jacques Gosteli, Hans Gschwend. James Hendrickson, Kenichi Hiroi. Ken Houk, Shô Itô, Bill Jencks. Tom Kat7. Andy Kende, Yoshi Kishi. Hoshiro Kobayashi, Jen-Marie Lehn. Willy Leimgruber, David Lemal, Paul de Mayo. Jerry Meinwald. David Ollis. Roy Olofson, Avram Patchornik, Suoramania Ranganathan, Myron Rosenblum, Dick Schlessinger, Franz Sondheimer, Baj Dattaraya Tilak, Denny Valenta, Harry Wasserman, Larry Weiler, Ernie Wenkert, Emil White, Mark Whiting, Alex Wick, Charles Wiesner, Reuven Wolovsky, Peter Yates, Alexander Gregoryevitch Yurlchenko, Howie Zimmerman.

It is inevitable, in preparing a list of this type, that some of the more famous colleagues should have been left out. These names I have added below.'
In May of 1944 The Tech (The MIT newspaper) made the following comment. "Professors who have known him well have stated that Woodward was excellent not only in chemical subjects but in academic studies as well." Those same professors would now have to admit that through the efforts of Robert Burns Woodward chemistry can at last be acclaimed a scholarly and academic pursuit.

And what of the future? You might imagine that the best answer to this question would come from the oracle himself. However, such pilgrimages are usually destined to failure. For example, I remember a press conference that was held on the morning that Bob won the Nobel Prize. A reporter from one of the local newspapers asked if he thought that he now would begin to synthesize life in the test tube. After a moment's reflection he looked up and said. "No, I am quite happy with the way it is done now."

After all of Woodward's scientific achievements one might imagine that there is nothing that he can do to exceed, for instance, the elegance or complexity of the $B_{12}$ synthesis. I am certain that this is not so, and that we shall see even greater triumphs in the future. If you doubt this statement I leave you with the words of Lewis Carroll:

"There is no use trying," she said; "one can't believe impossible things." "I dare say you haven't had much practice," said the Queen. "When I was your age, I always did it for half an hour a day. Why, sometimes I believed as many as six impossible things before breakfast."

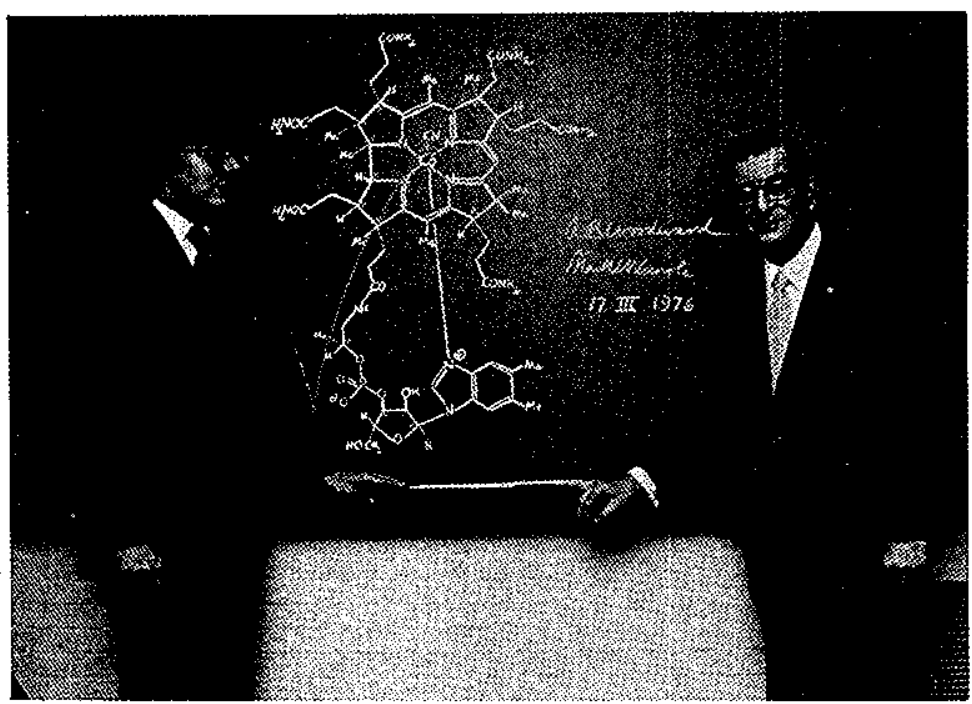

Fig. 7. Mark Wuonola and $R B W$ announce the completed synthesis of vitamin $B_{12}$ 
Footnotes:

1) F. Wöhler, Ann. d Physik, 12, 253 (1828).

2) F. Wöhler and J.v. Liebig, Justus Liebigs Ann. Chem., 26, 254 (1838).

3) This article is written as an appreciation of all that Woodward has done for chemistry in general and for me in particular, and is dedicated to him on the annive sary of his sixtieth birthday. If at any stage the reader should feel that my personal account transgresses the bounds of gentlemanly behavior, then I would refer them to the first piece of advice that Woodward ever gave me: "David, there is not time enough to worry over what others think about you."

4) I thought of changing your name, Pat, but I know, and you know, and he knows where the story comes from, so what's the point?

5) R. Anschütz, "August Kekulé 18291896 " in Great Chemists, ed. E. Farber, Interscience, New York, 1961, p. 697.

6) Sigmund Freud, The Interpretation of
Dreams, trans. A.A. Brill, completely revised edition (London: George Allen and Unwin, Ltd., 1937).

7) F. Haber, "Justus von Liebig 18031873" in Great Chemists, ed. E. Farber, Interscience, New York, 1961, p. 535.

8) In addition to papers, dedicated to Woodward on the occasion of his sixtieth birthday, which will be published throughout the scientific literature, Heterocycles, under the editorship of Tetsuji Kametani, will publish an issue containing papers dedicated to Woodward.

This year's Leermakers Symposium, to be held at Wesleyan University three weeks after Woodward's birthday, is to be built around the impact Woodward has made on total synthesis. Additional information on the symposium, of which Woodward is the Honorary Chairman, can be obtained from Professor Max Tishler, Department of Chemistry, Wesleyan Univesity, Middletown, CT 06457.

9) David Dolphin.

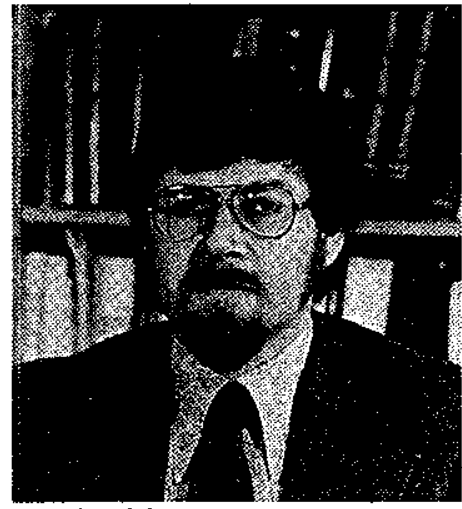

David Dolphin

\section{About the Author}

After obtaining his Ph.D. with Alan Johnson in 1965 David Dolphin spent a year's postdoctoral fellowship with Woodward, and he then joined the faculty of the chemistry department at Harvard where he stayed for eight years, moving in 1974 to his present location at the University of British Columbia. 